\title{
Efterundersøgelse af 300 unge prostituerede kvinder
}

\section{Af GUNNAR MORTENSSON og EMMA VESTERGAARD}

Fra Justitsministeriets psykiatriske Unders $\varnothing$ gelsesklinik afd. B.

Af et materiale på 457 unge halvt- og heltprostituerede kvinder, som er mentalunders $\varnothing \mathrm{gt}$ ved Justitsministeriets psykiatriske Unders $\varnothing$ gelsesklinik afd. B., har vi udtaget de første 300 og efterunders $\varnothing$ gt dem ved at samle så mange oplysninger som muligt om de pågældende. Vi har ikke ment, at en direkte personlig kontakt var gennemf $\phi$ rlig eller ubetænkelig, og har derfor begrænset os til at s $\phi$ ge oplysninger om kvindernes videre skæbne fra følgende kilder: Dansk Forsorgsselskabs tilsynsjournaler, Sædelighedspolitiet, Rigsregistraturen (også med hensyn til ægtefæller), M $\phi$ drehjælpsinstitutionen, en række psykiatriske hospitaler og Åndssvageforsorgen. De 300 efterunders $\phi$ gte kvinder er mentalunders $\phi$ gt $\mathrm{i}$ årene $1952-57$, som sigtede for overtrædelse af arbejdspålæg og af og til tilholdsbestemmelser, det vil sige straffelovens $\S 199 \mathrm{og}$, den nu ophævede, $\S 200$.

Efterunders $\phi$ gelsen er foretaget i årene $1960-64$. Vi har således opnået en observationstid på h $\varnothing$ jst 12 år og mindst 7 år, hvilket vi anser for en tilstrækkelig tidsperiode til vurdering af kvindernes senere skæbne.

Idet vi henviser til vor artikel i Nordisk Tidsskrift for Kriminalvidenskab, 1961, om 457 prostituerede kvinder, skal vi bemærke, at det drejede sig om unge kvinder i begyndelsesstadiet af prostitution, og som sigtede for overtrædelse af arbejdspålæg efter den almindelige praksis i K $\varnothing$ benhavn var blevet henvist til mentalobservation. De fleste af disse kvinder blev id $\phi \mathrm{mt}$ betinget straf, oftest 30 dages fængsel på vilkår af prøvetid i 2 år, af og til 3 år, og tilsyn af Dansk Forsorgsselskab i tilsvarende lang tid. Nogle af kvinderne har ikke фnsket tilsyn, og enkelte andre er straks i tilslutning til mentalunders $\varnothing$ gelsen blevet id $\varnothing \mathrm{mt}$ ubetinget fængselsstraf og har derfor ikke fảet tilsyn. - Vedrørende de pågældende kvinders status med hensyn til psykiatriske diagnoser, tidligere livsforl $\phi \mathrm{b}$ og retslige sanktioner kan i $\phi$ vrigt henvises til ovenfor nævnte artikel.

\section{Efterundersøgelsesresultater:}

Vi har inddelt efterunders $\emptyset$ gelsesmaterialet, 300 kvinder, i 3 grupper:

1: Kvinder, der må betegnes som resocialiserede allerede i tilsynsperioden. 
2: Kvinder, der senere er blevet resocialiserede.

3 : Kvinder, der ikke er resocialiserede på efterundersøgelsestidspunktet.

Når vi anvender udtrykket „resocialiseret“, tænker vi først og fremmest på kvindernes forhold med hensyn til prostitution og løsgængeri. Det vil sige, at hvis de pågældende kvinder ikke mere giver anledning til indgreb fra sædelighedspolitiets side, og efter alt, hvad der er oplyst, ikke mere lever parasitært eller løsagtigt, betragter vi dem som ,,resocialiserede“ — analogt med sædvanlig sprogbrug, når man taler om lovovertrædere. Vi tør ikke forlange, at de pågældende kvinder klarer sig godt socialt. Adskillige viser det sig — har så store фkonomiske og psykiske vanskeligheder - selv om de ikke er prostituerede - at vi ikke t $\phi \mathbf{r}$ anvende udtrykket ,stabiliserede“. Vi mener imidlertid, at vi her må koncentrere os om kvindernes skæbne med hensyn til prostitution og arbejdsforhold, og erkende, at vi i $\varnothing$ vrigt ikke med sikkerhed kan skelne mellem de kvinder, der klarer sig godt, nogenlunde eller dårligt socialt.

Herefter finder vi, at af de 300 kvinder er 56 resocialiserede allerede i tilsynsperioden, 159 er senere resocialiserede, og 84 var ikke resocialiserede på efterunders $\varnothing$ gelsestidspunktet. En kvinde er død så tidligt i nævnte tidsperiode, at vi den henseende ikke kan udtale os. - Ved afslutningen af unders $\varnothing$ gelsen finder vi således 215 resocialiserede og 84 ikke-resocialiserede.

Følgende 7 eksempler vil belyse resocialiseringsproblemerne:

\section{Eksempler på personer, der resocialiseres i tilsynsperioden:}

A. 1953: 21-årig, ugift kvinde. Haft gonorrhoe og underlivslidelser. Er fra et almindeligt, ordentligt barndomshjem. Var lidt tilbage i skolen. Huslige pladser. I 1 års tid ustabil, giver sig af med søfolk $\mathrm{i}$ provinsen og i København. Nægter særlige konflikter. Findes ved mentalunders $\phi$ gelsen at være sinke. Id $\varnothing$ mmes 30 dages fængsel betinget, på vilkår af 2 års prøvetid og tilsyn af Dansk Forsorgsselskab.

Iflg. tilsynsjournal: Hun anbringes på Fyn, hvor man får hende i gang på en konservesfabrik. Der klarer hun sig godt. Hun har dog nogle sygeperioder: tilskadekomst med en finger, pandehulebetændelse og senere underlivslidelse. - Trods disse legemlige handicaps ser det ud til, at hun stabiliseres. Hun får nyt godt arbejde i Odense på fabrik. I slutrapport af $\mathbf{1 7 . 1 0 . 5 5}$ noteres, at hun arbejdsmæssigt har klaret sig udmærket, men er nu igen sygemeldt og skal indlægges på sygehus. Har udviklet sig til en pæn og fornuftig pige. - Må betegnes som resocialiseret ved tilsynsperiodens oph $\varnothing$ r.

Intet negativt om hende siden.

B. 1955: 19-årig, ugift kvinde, der kalder sig ekspeditrice. Faderen drikfældig. Almindelig skole. Altid noget ustabil i pladser. Færdes pá 
amerikanerbarer. Ved unders $\emptyset$ gelsen betegnet milieuskadet. Id $\varnothing$ mmes

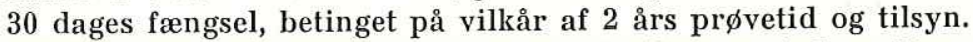

Iflg. tilsynsjournal: Hun retter sig i tilsynsperioden. Man støtter hende ved at finde beskæftigelse og med фkonomisk hjælp. — I 1956 får hun et barn, og i marts 1957 bliver hun gift med - såvidt man kan se - en stabil mand. Ved tilsynsperiodens afslutning d. 27.9.1957 har manden fast godt arbejde. Hun har tidligere selv haft beskæftigelse på chokoladefabrik, men $\varnothing$ konomien er nu så god, at hun kan blive hjemme og passe sit barn. - Må betegnes som resocialiseret ved tilsynsperiodens afslutning.

Intet negativt om hende fra retsvæsenet siden da.

Imidlertid ved vi f $\varnothing$ lgende fra M $\varnothing$ drehjælpen: Egteskabet disharmonisk. Hun henvender sig i 1958 for at bortadoptere et barn, hun fødte det år, vil giftes med en anden mand. Venter nu barn igen - får фkonomisk hjælp. - I 1962 gift (for 2. gang) med en maskinarbejder, som hun får et barn med, og har barnet hos sig. Senere et par spontane aborter. I 1963 påny henvendelse til Mødrehjælpen, er gravid, er nerv $\phi s$ for svangerskabet, uligevægtig og urolig, noget modl $\phi s$ og opgivende. Man finder, at der er indikation for abortus provocatus på grund af hendes nervøse tilstand.

C. 1952: 22-årig, ugift kvinde, der i 10 års alderen fik stedmoder, til hvem forholdet var svært disharmonisk. Siden da nervøse symptomer og tilpasningsvanskeligheder. Skolegangen dog almindelig. I tiltagende grad ustabil i huslige pladser, går i Nyhavn, misbruger spiritus. På unders $\varnothing$ gelsestidspunktet dec. 1952, betegnes hun konstitutionelt depressiv, neurotisk og frigid i $\mathrm{k} \phi$ nslig henseende. Psykiatrisk behandling tilrådes. Ved dom af 24.1.53: tilsyn af Dansk Forsorgsselskab i 3 år $(\S 70)$. - Retslægerådet, der blev forespurgt, ventilerede anbringelse af hende i psykopatforvaring. -

Ifølge tilsynsjournal: I det første års tid af tilsynsperioden er hun meget krævende både med hensyn til фkonomisk hjælp og til omsorg og bistand af enhver art, men uvillig til selv at gøre en virkelig indsats. Fortsætter også i perioder sin asociale tilværelse ved at søge til Nyhavn, pådrager sig også bøder for beruselse - og man overlader hende en tid til at klare sig selv. - I foråret 54 gravid, og søger Mødrehjælpen, der rejser faderskabssag for hende. I dec. 54 bliver hun gift med barnefaderen (om hvem vi intet negativt ved) og får sit barn hjem fra børnehjem. I 1955 får hun barn nr. 2. I ægteskabet stadige sociale og 6 konomiske vanskeligheder, men hun retter sig ganske væsentlig i psykisk henseende. Således konstaterer man i efteråret 1955, at hendes børn er velplejede, og at forholdet til ægtefællen er godt. - I slutrapport af 18.2.56 anføres, at det er opmuntrende at se, hvorledes det går hende. Således anskaffer hun sig stadig nye ting til sit hjem og er glad og stolt over sine børn, og hun synes tilfreds og i psykisk balance.

Fra Mødrehjælpen ved vi imidlertid, at hun i 1958 får barn nr. 3, 
og at hendes ægteskab betragtes som mislykket, hvad hun mente var hendes egen skyld. Hun er således altid træet, har blodmangel og kunne ikke passe sit hus, og omsider var ægtefællen fraflyttet hende - ind til nabokonen. De blev skilt, og Mødrehjælpen skaffede hende en lejlighed. Hun var stadig glad for sine børn. - I 1962 s $\emptyset$ gte hun igen Mødrehjælpen, og var da gravid for 4. gang. Barnefaderen var separeret arbejdsmand, (ifølge Rigsregistraturen: småkriminel). Hun fortalte, at han drak spiritus og $\mathrm{i}$ beruset tilstand var brutal og voldsom overfor hende, så hun var angst for ham. De boede sammen i en 2-værelses gammeldags lejlighed, og $\phi$ konomien var elendig. Selv skaffede hun penge til huse ved at arbejde på en restaurant som oprydderske. Ifølge børneværnet, der førte tilsyn med hendes børn, vidste man, at hun selv af og til, når hun var langt nede, søgte trøst i spiritus, men man opfattede hende alligevel som temmelig stabil. Mødrehjælpen stillede indikation for abortus provocatus og anbefalede sterilisation. Imidlertid angav hun senere, at hun ville gennemf $\phi r e$ svangerskabet, $o g$ at hun ville fortsætte samlivet med barnefaderen (dec. 1962).

\section{Eksempler på personer, der senere er blevet resocialiseret.}

D. 1953: 22-årig, ugift kvinde fra provinsen. Haft travle, flittige forældre, der senere blev skilt. D. har altid været rastl $\emptyset$ s og neurotisk. Almindelig skole. Senere noget ustabil i huslige pladser. Efter et par erotiske skuffelser hengiver hun sig til restaurationsliv på barer i det indre København, hvor hun indlader sig med mænd af direktørtypen. Ved unders $\emptyset$ gelse i januar 1953 findes hun neurotisk. — Idømmes 30 dages fængsel betinget, på vilkår af prøvetid og tilsyn i 2 år.

Iflg. tilsynsjournal: Får en del hjælp, også økonomisk, fra Forsorgsselskabet, men har svært ved at tilpasse sig socialt, drikker for meget spiritus; hendes levevis urolig. Et par gange anbringes hun i pigehjemmet „Bartholinsgade“ og må behandles på hospital for kønssygdomme. Det synes, som om hun glider længere og længere ud i asocialitet. I juli 1953 antræffes hun sammen med 3 mænd, der er i færd med at give hende en indsprøjtning af et narkotisk middel, og det er indtrykket, at hun er forfalden til misbrug af medikamenter. Man fortsætter dog hjælpebestræbelserne, men uden held. — I august 1953 idømmes hun (fælles-) straf på 3 måneder for overtrædelse af arbejdspålæg og tilholdsbestemmelser. - Hun afsoner. I juni 1954 idømmes hun 60 dages fængsel for tyveri, som hun også afsoner. - Herefter intet negativt om hende fra retsvæsenets side.

Vi ved yderligere, at hun i 1955 giftede sig med en nyhavnsmusiker. Med ham fik hun 2 børn. Hun var ægtefællen utro, og de blev skilt i 1959. Hun gav da afkald på det æeldste barn. I 1960 henvendte hun sig til Mødrehjælpen og fortalte, at hun stærkt fortrød, at hun havde ladet sig skille, navnlig fra sit barn. Var for nylig blevet gift igen, med en håndværker, (der iflg. Rigsregistraturen er småkriminel). Dette ægteskab dårligt, idet manden var besværlig, aldrig gav hende rede penge, 
slog hende, kom med bebrejdelser o. s. v.. Hun var nu gravid med ham, og manden ville, hun skulle gå til kvaksalver, D. $\emptyset$ nskede imidlertid at bo alene - med sit barn, født 1958. - Hun klagede over dårlige nerver, angstfornemmelser, hjertebanken m. m., og ønskede abort. Senere angav hun at ville f $\varnothing$ de barnet, og hun fik en $s \varnothing \mathrm{n}$ i april 1961.

E. 1954: 18-årig, ugift kvinde. Drikfældig fader og brudt hjem. E. har gået $\mathrm{i}$ hjælpeklasser. Været ustabil i fabrikspladser, som hun har vanskeligt ved at tilpasse sig. - Færdes i Nyhavn og misbruger spiritus. - Ved unders $\emptyset$ gelse betegnes hun sinke og slap af karakter. Id $\varnothing$ mmes 30 dages fængsel, betinget på vilkår af prøvetid i 2 år under tilsyn af Dansk Forsorgsselskab.

Iflg. tilsynsjournal: Man fors $\varnothing$ ger at anbringe hende i plads, men hun bortgår, virker fortsat ustabil og har kun kortvarige beskæftigelser. Periodisk færdes hun påny i Nyhavn og forekommer „hårdkogt og sjusket“. I sommeren 1955 misbruger hun i særlig grad spiritus, men afslår antabuskur. - I august 1955 idømmes hun 60 dages fængsel (fællesstraf) ubetinget for overtrædelse af arbejdspålæg og tilholdsbestemmelser. - Det ses videre, at hun i oktober 1956 påny id $\varnothing$ mmes ubetinget 3 måneders fængselsstraf for lignende forseelser. I februar 1957 sigtes hun igen for lignende forhold, men sagen bliver henlagt.

Siden intet negativt om hende fra retsvæsenets side.

Imidlertid ved vi om E. fra Mødrehjælpen, hvor hun var sidst i efteråret 1964: Hun var stadig ugift, havde fået en s $\varnothing$ n i 1957, en anden søn i 1959. — Forår 61: Bad om økonomisk hjælp, boede alene med sine børn, fik socialhjælp + børnetilskud, men havde svært ved at klare sig og var trist og nervøs. - Efterår 61: Bad om at få sin lys- og gasregning betalt. - Febr. 62: Arbejdede og havde stadig b $\phi$ rnene hos sig. - Okt. 63 fødte hun en datter. Febr. 64: Bad om hjælp til k $\varnothing$ jesenge. Efterår 64: S $\varnothing$ gte nu hjælp vedrørende faderskabssag i anledning af sidste barn og anmodede samtidig om hjælp til at få ny lejlighed. Hun fortalte, at hun havde boet sammen med barnefaderen i 3 år, og at han også var fader til sønnen f. i 1959. Han var havnearbejder (ukendt i Rigsregistraturen) og drak meget spiritus, og de var ofte uvenner og boede $i$ en meget ringe lejlighed. E. var ikke interesseret i giftermål med ham, men ville gerne steriliseres og helst klare sig selv. -

\section{Eksempler på kvinder, der på efterundersøgelsestidspunktet ikke er resocialiseret.}

F. 1954: 18-årig, ugift fabriksarbejderske. Fra ringe milieu, begge forældre straffede og begge drikfældige. Moderen småtbegavet, har drevet utugt. - Forkvaklet opdragelse, på børnehjem som barn. Færdes på amerikanerbarer. Ved mentalunders $\varnothing$ gelse i december 1954: milieuskadet og spiritusmisbrugende. Id $\phi$ mmes 30 dages fængsel betinget, på vilkår af 3 års prøvetid og tilsyn af D. F. 
Af tilsynsjournal: F. fortsætter med at være løsagtig og ustabil, bor en tid hos forældrene, der ikke kan holde styr på hende. - Man forsøger at skaffe hende arbejde, men hun synes arbejdssky, er ikke interesseret $\mathrm{i}$ at samarbejde med tilsynet, og det ender med, at hun $\mathrm{d}$. 30.5.1955 idømmes fællesstraf af 60 dages fængsel for overtrædelse af arbejdspålæg og tilholdsbestemmelser.

Det viser sig, at hun senere 2 gange, i 1956 og 1957, straffes for lignende forhold. 1958 gives påny arbejảspålæg. I 1959 gifter hun sig med en lagerarbejder, der if $\varnothing l g e$ Rigsregistraturen er ,,alvorlig kriminel“. Dette år henvender hun sig i Mødrehjælpen og beder om hjælp i anledning af f $\varnothing$ dsel. Hun får også en s $\varnothing \mathrm{n}$ i august 1959, beklager sig over legemlige sygdomme, men arbejder ind imellem på fabrik. I 1960 angiver ægtemanden til Mødrehjælpen, at hun „er forsvundet“, og at hun solder på værtshuse, formentlig amerikanerbarer, og nu vil han separeres eller skilles. I efteråret $1960 \mathrm{er}$ hun igen gravid og søger svangerskabsafbrydelse, da skilsmisse nu igen er på tale. Hun beklager sig over, at manden er drikfældig, hun selv har dårlige nerver og ,har haft gonorrhoe ca. 10 gange“. Et barn hun fik i 1955 er hos hendes forældre, barn nr. 2 er bortadopteret, men hun har barn nr. 3 hos sig. Tilstår utugtsdriven, ser ældet, hærget og trist ud. Man finder indikation for abortus provocatus efter svangerskabslovens $\S \S 1,1,3-4$. Senere vil hun alligevel gennemf $\varnothing$ re svangerskabet, og $\mathrm{i}$ foråret 1961 får hun en datter og anfører, at hun igen er flyttet sammen med ægtefællen. - I efteråret 1961 henvender hun sig påny i Mødrehjælpen og angiver (med bevis), at hun er skilt i juni 1961. Hun (siger, at hun) har forældremyndigheden over 2 børn og ønsker hjælp med hensyn til bidrag, beder om forskud til indk $\varnothing \mathrm{b}$ af t $\varnothing \mathrm{j}$ til sine børn og gør et ubehjælpsomt indtryk. Man yder hende forskellig hjælp.

G. 1955: 21-årig, ugift kvinde. Faderen drikfældig, småtbegavet, brutal og hidsig. - Fattig, forkvaklet opdragelse. Almindelig skolegang. Forskellige legemlige svagheder. Ustabil i arbejde, på ungdomshjem i perioder. Færdes i Nyhavn. Ved undersøgelsen i foråret 1955 betegnet milieuskadet. Id $\varnothing$ mmes 30 dages fængsel, betinget på vilkår af prøvetid og tilsyn i 2 år.

Af tilsynsjournal: Det går ikke godt i tilsynsperioden. G. går i Nyhavn, drikker en del, kan ikke beskæftiges. 9.3.1956 id $\varnothing$ mmes hun 60 dages fængsel ubetinget.

Senere i-1956 afsoner hun påny fængselsstraf for overtrædelse af arbejdspålæg og tilholdsbestemmelser. I 1962 sigtet igen for lignende forhold og meddelt nyt pålæg. I 1962 afsoner hun igen 2 gange for samme forseelse.

Dansk Forsorgsselskab d. 4.2.1963: Påny sigtet for overtrædelse af $\S 199$, og der er tale om antabusbehandling. Man prøver at få hende til at akceptere evt. vilkår, så hun kan opnå en betinget dom. Det lykkes imidlertid ikke. Hun vil ikke gennemgå ny afvænningskur, idet hun „har prøvet“ en sådan ambulant kur i 1962, men tålte den ikke, 
fik voldsomme angstanfald med kvælningsfornemmelser af antabus. - Selv angiver hun, at hun er meget svær at hjælpe - kan lide det løsagtige liv, og hader enhver tvang. Har i de senere måneder drukket voldsomt, ca. 40 genstande i døgnet. Idømmes d. 6.2 .196330 dages fængsel ubetinget.

I 1963 på Bornholm ,indlagt i sygehus efter indtagelse af piller“. -

Andre påviste forhold af interesse:

Tilsyn og afsoning af den betingede dom: Hvis kvinderne fortsætter med løsagtig levevis eller atter overtræder arbejdspålæg, eventuelt begår anden kriminalitet, må de afsone den betingede straf. Afsoning kommer som bekendt i stand for de kvinders vedkommende, der har tilsyn, ved at Forsorgsselskabet opgiver dem som negativt reagerende på selskabets hjælpeforanstaltninger.

Vi finder, at blandt dem vi betegner resocialiserede har $1 / 3$ afsonet, blandt de ikke-resocialiserede har $2 / 3$ afsonet den betingede straf.

41 af de 300 kvinder har ikke haft tilsyn. Deraf har $1 / 4$ (11) af sonet den betingede straf. - Vi finder yderligere, at $2 / 3$ af de nævnte 41 er resocialiserede på unders $\varnothing$ gelsestidspunktet. — Til sammenligning anf $\varnothing$ res, at vi i hele materialet finder $3 / 4$ resocialiserede.

Ovenstående forekommer os at være udtryk for, at strafafsoning ikke har sikker virkning som prostitutionsforebyggende foranstaltning, endvidere synes tilsynsforanstaltninger at have mindre overbevisende positiv effekt, end man skulle have ventet. Det synes da, som om resocialisering er ligeså afhængig af andre forhold som af straffuldbyrdelse og af tilsyn.

Almindelig kriminalitet: Kun 14 af de 300 kvinder er d $\phi \mathrm{mt}$ for andre lovovertrædelser: Det drejer sig her næsten udelukkende om berigelsesforbrydelser og for enkeltes vedkommende om udbredelse af venerisk smitte. Alvorligere kriminalitet forekommer imidlertid ikke i vort materiale. Det er ret bemærkelsesværdigt, at så få af vore kvinder g $\phi \mathbf{r}$ sig skyldig i tyveri, og alt i alt finder vi, at 14 af 300 er et ringe antal. Såvel dette som kvindernes livshistorie sammenholdt med alt, hvad vi har fået oplyst om dem, peger i retning af, at de ikke er kriminelle $\mathrm{i}$ betragtning af, hvad udtrykket kriminalitet $\mathrm{i}$ almindelighed indebærer. Det må indrømmes, at de har hengivet sig til en særlig leveform, som man kan akceptere eller ej, men som samfundet i hvert fald ikke akcepterer. Alt taget $\mathrm{i}$ betragtning finder vi det imidlertid betænkeligt at bibeholde kriminaliseringen af de her omhandlede kvinder.

Psykiske defekter: Når vi sammenholder vore tal for de resocialiserede med de psykiatriske diagnoser, vi stillede ved men- 
talunders $\phi$ gelsen i sin tid, finder vi, at blandt de 215 , som vi nu finder resocialiserede, er 50 , d. v. s. knapt $1 / 4$, tidligere betegnet som karakterafvigende, d. v. s. enten som psykopater eller som karakterneurotikere. (Vi har betragtet disse 2 kategorier under. eet, idet man vanskeligt i praksis kan skelne mellem dem). Af de 84 , som vi nu betegner som ikke-resocialiserede, finder vi 33 ; karakterafvigende, altså ca. $2 / 5$. - Dette tyder på, at de ikkeresocialiserede først og fremmest findes blandt de psykisk belastede, hvilket naturligvis ikke kan overraske.

For de kvinder, der ved mentalunders $\varnothing$ gelsen er betegnet som ,,ikke psykisk afvigende“ g $\phi \mathbf{r}$ den modsatte tendens sig gældende, idet udsigterne for disse kvinder er bedre end for de psykisk.
belastede.

Psykiske tilpasningsvanskeligheder $i$ efterundersøgelsesperioden: Ovenstående verificeres yderligere af de oplysninger, vi har opnået om psykiske tilpasningsvanskeligheder i efterunders $\phi$ gelsesperioden, belyst i hospitalsjournaler m. v. - Det drejer sig i overvejende grad om depressioner og affektlabilitet.

Vi har således noteret psykiske tilpasningsvanskeligheder hos ca. $1 / 5$ blandt de resocialiserede, men hos $2 / 5$ blandt de ikke-resocialiserede. (Hos henholdsvis 43 af 215 og 32 af 84 ).

Hvad angår misbrug af alkohol og narkotika, er vore fund ganske overbevisende, idet vi har oplysninger om, at 1/4 (21 af 84) blandt de ikke-resocialiserede er misbrugere, men kun $1 / 15$
(14 af 215) blandt de resocialiserede.

Egteskab: Vi har i særlig grad interesseret os for de pågældende kvinders agteskabelige forhold. Det må indrømmes, at det har været svært at skaffe n $\emptyset$ jagtige oplysninger desangående, og det er sandsynligt, at adskillige af kvinderne har indgået ægteskab, uden at dette er kommet til vort kendskab. Vi ved imidlertid, at af de 215 resocialiserede har de 88 giftet sig i almin-
delige kår. Hermed mener vi, at delige kår. Hermed mener vi, at der ikke foreligger negative op-
lysninger om ægtefællen, hverken med hensyn til kriminalitet eller asocialitet. Vi ved altså, at $2 / 5$ af de resocialiserede har indgået et almindeligt ægteskab. Imidlertid har vi fundet, at kun $1 / 10$ (8 af 84 ) af de ikke-resocialiserede har indgået et sådant
almindeligt ægteskab.

Ved registrering af uheldige ægteskaber, d. v. s. med mænd, der er karakterdefekte, asociale, alkoholiske eller kriminelle, bliver resultatet henholdsvis $1 / 10$ (24 af 215) og $1 / 5$ (17 af 84) for de resocialiserede og for de ikke-resocialiserede kvinders vedkom-
mende.

„Kun“ kriminelle ægtefæller registrerer vi hos 9 af 215 resocialiserede og hos 6 af 84 ikke-resocialiserede, (tallene sk $\phi$ nnes
at være for små til brøkdelsberegning).

Disse kendsgerninger sammenholdt med oplysninger i tilsyns- 
journalerne tyder på, at der er en sammenhæng mellem resocialisering og giftermål i almindelige kår, og det er sandsynligt, at ,stabile ægteskaber“ virker resocialiserende, uden at vi dog af vore tal kan fremf $\phi$ re bevisligheder.

Bфrn: På forhånd har vi formodet, at eventuelt moderskab ville have stor betydning i positiv retning for vort klientel, og sådant har vi da også kunnet udlede af en del journaler. Et begrundet sk $\phi$ n kan vi imidlertid ikke afgive desangående, idet det beklageligvis ikke har været os muligt at opnå tilstrækkelige oplysninger om hvor mange af vore kvinder, der har f $\varnothing \mathrm{dt}$ b $\phi \mathbf{r n}$ i efterunders $\varnothing$ gelsesperioden, ej heller om hvor mange, der som mødre selv opdrager deres børn eller overlader dem til det offentlige.

Idet vi således pointerer, at de oplysninger, vi har om f $\varnothing \mathrm{dsler}$ i efterunders $\phi$ gelsesperioden, absolut må være minimumstal, kan vi anf $\phi r e$, at vi ved, at 54 af de 300 kvinder har født b $\phi \mathbf{r n}$ i nævnte tidsperiode, herunder 30 af de 215 resocialiserede og 14 af de 84 ikke-resocialiserede.

Legemlige svagheder: I vore oprindelige mentalerklæringer og i journalerne fra Forsorgsselskabet, fra hospitaler og fra M $\phi$ drehjælpen ser vi ofte, at kvinderne frembyder adskillige legemlige svagheder, herunder især underlivslidelse. Dette kan ikke undre, når henses til, hvor ofte veneriske sygdomme (især gonorrhoe) forekommer blandt klientelet. $\mathrm{Da}$ underlivssygdomme af mere eller mindre kronisk art i særlig grad forårsager træthed og blodmangel og deraf følgende ulyst til arbejde, insufficiensf $\varnothing$ lelse, mismod og forstemninger, føler vi trang til at påtale, at der almindeligvis tages for ringe hensyn hertil. Dette gælder ofte ved den retslige reaktion overfor disse kvinder, især når man betænker, at deres forseelse er stemplet som unddragelse af pligten til at klare sig selv ved hæderligt arbejde - omend en camoufleret form for straf for utugt. Imidlertid finder vi, at der også senere - efter domsafg $\phi$ relsen — under tilsynsperioden — og ved nye afh $\phi$ ringer hos politiet o. s. v. - burde tages større hensyn til legemlige svagheder, end tilfældet er, - ikke blot ved at etablere lægelige behandlinger, men også ved vurdering af, hvilket krav om arbejdsydelser man med rimelighed kan forvente opfyldt fra de pågældende kvinders side.

Sjælelige depressioner - herunder d $\phi d s f a l d:$ Som ovenfor antydet forekommer periodisk optrædende depressive tilstande jævnligt hos vore kvinder, hvilket har afspejlet sig i hospitalsjournalerne. - 28 af de 300 kvinder har foretaget et eller flere selvmordsfors $\phi \mathrm{g}-11$ af de 300 er d $\varnothing$ de i efterunders $\phi$ gelsesperioden, og for de 6's vedkommende ved selvmord. For de 5's vedkommende kender vi ikke dødsårsagen. 
Alt taget i betragtning vil vi mene, at en mere konstant og effektiv lægelig, herunder psykiatrisk kontrol og behandling end hidtil etableret af de kvinder, der måske efter tilsynets sk $\phi$ n findes lidende af stemningssygdomme er påkrævet, og dette ville formentlig være af væsentlig positiv betydning som stabiliserende faktor.

Oprindeligt tilholdssted: Betragter vi resocialiseringsproblemet ud fra kvindernes oprindelige tilholdssteder: Amerikanerbarer, Nyhavn og Vesterbro, og sammenholder resultaterne med vort oprindelige materiale (bestående af 457 kvinder - se vor attikel af 1961), finder vi, at prognosen er afgjort bedst for Amerikanerpigerne og dårligst for Nyhavnspigerne. Vesterbroklientelets antal er så ringe, at man ikke kan drage sikre slutninger, men det ser ud til, at resocialiseringstendensen også her er større end for Nyhavnspigernes vedkommende.

\section{Sammenfattende.}

Vi har efterunders $\phi$ gt 300 kvinder, som vi har mentalunders $\phi$ gt i årene 1952 - 57, da de var sigtede for overtrædelse af arbejdspålæg.

Vor observationstid er højst 12 og mindst 7 år.

Det viser sig, at $3 / 4$ af kvinderne resocialiseres $i$ den nævnte tidsperiode $\mathrm{i}$ den forstand, at de ikke mere giver anledning til indgriben fra sædelighedspolitiets side.

Vor unders $\varnothing$ gelse viser imidlertid også, at adskillige legemlige og åndelige svagheder, brist og sygdomme er fremtrædende i klientelet, også blandt dem vi betegner resocialiserede. Flere af disse og især de ikke-resocialiserede har så store psykiske og sociale problemer, at vi ikke tør anvende udtrykket ,stabiliserede".

Dårligst prognose har de kvinder, der i sin tid blev betegnede karakterafvigende.

Betragtet ud fra oprindeligt tilholdssted: Amerikanerbarer, Nyhavn og Vesterbro, er prognosen dårligst for Nyhavnspigerne.

Almindelig kriminalitet er sjældent forekommende blandt de efterundersøgte kvinder.

Vi finder ikke beviser på, at strafafsoning (af den betingede straf) virker befordrende med hensyn til resocialisering, selv om vi næppe heller kan slutte det modsatte ud fra vor opg $\varnothing$ relse.

For en del af kvinderne er der ikke etableret tilsyn. For andres vedkommende er tilsynet oph $\phi$ rt ved straffuldbyrdelse. Det er bemærkelsesværdigt hvormange af disse kvinder, der alligevel klarer sig. Vor gennemgang af tilsynsjournaler og den $\phi$ vrige efterunders $\varnothing$ gelse giver os den opfattelse, at tilsyn har stor værdi, men at tallene ikke på overbevisende måde demon- 
strerer n $\phi$ dvendigheden af en tilsynsordning under de givne former.

Efter alt at dømme er ægteskab - i almindelige kår — en væsentlig positiv faktor med hensyn til resocialisering.

\section{Bemærkninger og forslag:}

Arbejdet med disse kvinder og vor efterunders $\varnothing$ gelse giver os anledning til f $\varnothing$ lgende bemærkninger:

Tilsynsperioden forekommer os urimelig lang, når henses til følgende:

1) Den ringe forseelse kvinderne efter vort sk $\phi$ n har gjort sig skyldig i.

2) De d $\phi$ mtes unge alder.

3) Den sædvanligt id $\varnothing$ mte fængselsstraf: 30 dages fængsel (undertiden kun 20) med fradrag af gennemsnitligt 1 uge for udstået varetægtsfængsel, d. v. s. 22 dage eller endnu mindre. - Afsoning af en så kortvarig straf kan for en trodsigt reagerende ung person være at foretrække frem for en 2-årig tilsynsperiode med store indskrænkninger i hendes personlige frihed.

4) Den tilsynstid der dekreteres, når betinget straf idømmes ved grovere kriminalitet. Også i relation til tilsynstiden for pr $\varnothing$ vel $\varnothing$ sladte fængselsfanger, hvilken i praksis sjældent er mere end 2 år, ligesom tilsynstid for en person, der benådes for $1 / 2-1$ års fængselsstraf jævnligt ikke er af mere end 1 års varighed.

Det skal anføres, at det ikke i det materiale, der har været til vor rådighed, har været os muligt at finde noget egentligt kriterium for fastsættelsen af tilsynsperiodens længde. Retfærdigvis må vi dog oplyse om, at det var i årene indtil 1954, at en tilsynsperiode på 3 år af og til anvendtes, mens 2 år senere --også for tiden - er almindelig praksis. Vi har heller ikke kunnet se, om det fra rettens side har været tillagt betydning, om de tiltalte var egentlig utugtsdrivende eller ej.

Som vi tidligere har beskrevet, er de fleste af vore kvinder ikke egentlig utugtsdrivende i den forstand, at de (bevisligt) fordrer eller modtager penge for sexuelle ydelser.

Også det indtryk, vi har fået ved gennemlæsning af ca. 250 tilsynsjournaler fra Dansk Forsorgsselskab, taler for en afkortning af tilsynsperioden. En sådan afkortning ville formentlig fremme intensitet og effektivitet. En vurdering af materialet efterlader det indtryk, at der i ikke så få tilfæelde er hengået uger — i enkelte tilfælde måneder — f $\varnothing$ rend der er blevet skabt kontakt med kvinder, der er udeblevet fra aftalt møde med den 
tilsynsførende. Efter vor formodning burde eftersøgning i disse tilfælde iværksættes, så snart udeblivelsen er en kendsgerning. At dette kan støde på praktiske vanskeligheder, er vi klar over, men finder ikke desto mindre at måtte gøre opmærksom derpå.

Vi skønner, at tilsynsperioden for denne særlige kategori af lovovertrædere - de sædvanlige sanktionsformer forudsat - i fremtiden normalt $b \phi r$ være højst 1 år. Endvidere $b \phi r$ tilsynet med klienten gennemf $\varnothing \mathrm{res}$ med n $\varnothing \mathrm{je}$ kontakt, herunder fremmøde hos den tilsynsf $\varnothing$ rende, f. eks. 1 gang ugentligt på forud fastsat tid, samt med $\varnothing$ jeblikkelig fremskaffelse af klienten ved hendes eventuelle udeblivelse. En sådan ordning ville forekomme os mere rimelig, alle forhold taget i betragtning. Den ville formentlig også være mere effektiv end den nu praktiserede tilsynsordning, idet vi skønner, at klienterne ville reagere positivt på sådant, ligesom den nævnte fremgangsmåde måske ville skabe større respekt hos klienterne for tilsynsinstitutionen.

Imidlertid kan man diskutere betimeligheden af at kriminalisere disse kvinder. - Praktiseringen af straffelovens $\S 199-$ og tidligere $\S 200-\mathrm{i}$ forbindelse med den praksis, der i hvert fald for K $\phi$ benhavns vedkommende f $\phi$ res, er i virkeligheden et udtryk for en maskeret kriminalisering af heterosexuel prostitution. - En sådan kriminalisering kan vi ikke akceptere. Givet er det, at samfundet har interesse $i$ at hjælpe disse kvinder, der for st $\varnothing$ rstedelen er unge, og det er klart, at det er vanskeligt at gennemf $\varnothing$ re positive foranstaltninger over for dem, hvis sådanne ikke gøres betinget af en eller anden form for reaktion. - I dag bruger vi straffetruslen, og hvis denne ikke virker, da afsoning. Som det fremgår af vort materiale, drejer det sig om kvinder, der ikke kan betegnes kriminelle i dette ords almindelige betydning. Alligevel behandler samfundet dem på samme måde som egentlig kriminelle, evt. ved afsoning i kvindefængslet i Horse-
rød.

Dette finder vi ikke rimeligt. Spørgsmålet er, om man kunne finde metoder, der kan føre til de pågældendes resocialisering ligeså effektivt, evt. mere effektivt end det nuværende system.

Allerede for ca. 10 år siden (i 1956) fremkom prostitutionskommissionen med forslag om - overfor de pågældende kvinder - at anvende sanktioner af social art, evt. i form af tvangsmæssig anbringelse i særlige institutioner med karakter af ungdomspensioner. Disse forslag blev ikke gennemf $ø$ rt på Rigsdagen, der iøvrigt i de senere år har vedtaget lovbestemmelser til imødegåelse af eventuelle uretfærdige indgreb i ,personlig frihedsberøvelse“. Det forekommer os, at de foranstaltninger, der fortsat iværksættes overfor den type unge kvinder, som vi her beskæftiger os med, er af langt alvorligere frihedsberøvende art end de i kommissionsbetænkningen anf $\varnothing r t e$.

Vi ønsker påny at henlede opmærksomheden på disse forslag, 
der efter vort sk $\phi$ n indebærer muligheder for at opnå de $\phi$ nskede resultater, såsom en arbejdsmæssig træning af de pågældende kvinder samt lægelig kontrol og behandling af deres eventuelle legemlige og åndelige brist.

Hvis man imidlertid fortsat vil anvende frihedsstraf som sanktionsform, mener vi, at man snarere burde anvende hæftestraf fremfor fængselsstraf. De omhandlede lovovertrædelser ville derved blive vurderet som „lettere“ og ikke som vanærende. Den strafferetlige vurdering af de pågældende kvinder ville dermed komme på linie med en speciel gruppe lovovertrædere som f. eks. "spritbilister" (for hvem normalstraffen er hæfte i 20 dage).

Vi f $\varnothing$ ler os da tilskyndet til at fremkomme med f $\varnothing$ lgende:

Hvis man fortsat vil kriminalisere:

a) $\mathrm{B} \phi \mathrm{r}$ hæftestraf under betingede former anvendes, $\mathrm{i}$ stedet for fængselsstraf.

b) Tilsynsperioden b $\phi \mathbf{r}$ normalt kun være 1 år.

c) Samtidig tilrådes en effektivisering af tilsynet med omgående etablering af kontakt ved eventuel udebliven og negligeren fra klientens side. Endvidere for $\varnothing$ get omhu og foranstaltninger med hensyn til klientens legemlige og åndelige brist.

Hvis man opgiver kriminaliseringen, hvad man efter vort sk $\phi n$ b $\phi \mathbf{r}$ g $\varnothing \mathbf{r e}$, tilrådes :

Foranstaltninger mod de pågældende kvinder, som i prostitutionskommissionens betænkning af 1956 anf $\phi$ rte. Herunder, om forn $\varnothing$ dent og tilrådeligt, en anbringelse - $\mathrm{i}$ analogi med anbringelse på arbejdsanstalter -i et ungdomshjem eller -pension i 3-6 måneder med efterfølgende tilsyn i henholdsvis $9-6$ måneder, så tilsynsperiodens længde fortsat normalt kun bliver et år.

Det er endvidere nærliggende, når diskussionen står om reaktion overfor unge kvinder, der har unddraget sig arbejdspligt, at henlede opmærksomheden på betimeligheden af at forlange en „samfundstjeneste" af kvinder, i analogi med mændenes militærtjeneste. En sådan form for pligttjeneste for kvinder ville utvivlsomt have stabiliserende virkning på adskillige, også af „vore“ kvinder, såvel legemligt som psykisk og socialt.

Betragtninger vedrørende prostitutionens årsager ligger udenfor denne artikels rammer, men vi undlader ikke at efterlyse en mentalitetsændring med hensyn til problemerne omkring prostitution og sexualitet. En sådan ændring må tage sigte på opdragelse af ungdommen, af drenge såvel som af piger, og $\mathrm{i}$ denne forbindelse vil vi blot her antyde $\varnothing$ nsket om en st $\varnothing$ rre pointering, end almindeligt er, af læren om driftsliv, sexuelle af vigelser og f $\phi r s t o g$ fremmest etik i den allerede forekommende, men især fysisk betonede, sexualoplysning.

Gunnar Mortensson og Emma Vestergaard. 